\title{
AUTOMATISCHE INFORMATIEVERWERKING EN ORGANISATIETHEORIE*
}

Eerste generatie toepassingen versus derde generatie mogelijkheden

door Drs. A. Bosman

\section{Inleiding}

Een schets van het verband tussen de automatische informatieverwerking en de organisatietheorie geeft een onjuist beeld, indien men er van uitgaat dat de relatie tussen beide wordt bepaald door een eenrichtingverkeer van de eerste naar de tweede. ${ }^{1}$ ) Voor zowel theorie als praktijk is van belang dat er relaties in beide richtingen bestaan. Deze wederzijdse relaties vormen de rode draad die de verschillende onderdelen van dit artikel met elkaar verbindt.

In par. 2 zal worden uiteengezet welke de belangrijkste ontwikkelingen, naar de neming van de schrijver althans, in de organisatietheorie gedurende de laatste twee decennia zijn geweest en waar deze hun oorsprong vinden. De rol die de rekenautomaat daarbij heeft gespeeld, is die van instrument. Een voor de ontwikkeling van de organisatietheorie belangrijk instrument, maar tot op dit moment ook niet meer dan dat. Juist dit feit remt de ontwikkeling van de toepassingsmogelijkheden van de automatische informatieverwerking. Er zal bij de verdere ontwikkeling van de organisatietheorie meer rekening moeten worden gehouden met de mogelijkheden die de derde generatie rekenautomaten bieden. ${ }^{2}$ ) Alhoewel de schrijver zich bewust is van het feit dat de toepassingsmogelijkheden van de derde generatie rekenautomaten vaak worden overschat en dat de problemen rond de programmering en de invoering ervan worden onderschat, zijn de technische mogelijkheden ruimer dan op dit moment in de praktijk wordt gerealiseerd. Het is vooral het ontbreken van een aan deze technische mogelijkheden aangepaste organisatietheorie die veroorzaakt dat we ons nog altijd ,,behelpen" met eerste generatie toepassingen. In par. 3 en 4 zullen enkele oorzaken hiervan worden genoemd, terwijl in par. 4 de hoofdlijnen van een nieuwe theorie zullen worden beschreven. In par. 5 tenslotte zal op de noodzaak van de ontwikkeling van een dergelijke theorie nader worden ingegaan, terwijl enkele raakpunten met de bestaande organisatietheorieën zullen worden genoemd.

\section{De ontwikkeling van de organisatietheorie}

De organisatie is object van studie van vele wetenschappen. Gegeven de verschillen

*) De schrijver dankt de heren Prof. Dr. J. L. Bouma, A. J. van 't Klooster en Prof. Dr. A. Wattel voor hun opmerkingen naar aanleiding van een concept van dit artikel. Het spreekt vanzelf dat alleen de schrijver verantwoordelijk is voor de fouten.

1) Een scherpe afbakening van het werkterrein van de theorie der organisatie valt moeilijk te geven. Wel kan worden opgemerkt dat dit, onder invloed van de hierna te schetsen ontwikkeling, steeds ruimer wordt. Onder een organisatietheorie wordt hier verstaan elk samenstel van hypothesen waarmee men een verklaring tracht te geven van het "gedrag" van een organisatie. De inhoud van de organisatietheorie zal verschillen voornamelijk ten gevolge van het feit hoe men het zgn. „gedrag" van een organisatie wenst te interpreteren. De organisatietheorie in deze betekenis is beperkter van inhoud dan het begrip "management”, dat men zou kunnen vertalen met beheer of leiding.

2) $\mathrm{Bij}$ de vertaling van de veelal Angelsaksische terminologie op het gebied van de automatische informatieverwerking is gebruik gemaakt van: Woordenlijst informatieverwerking, Nederlands Normalisatie Instituut, 3386, november 1967. 
in kenobjekt tussen deze is het niet mogelijk te spreken over de organisatietheorie. ${ }^{3}$ ) De door de verschillende disciplines opgestelde hypothesen zijn soms strijdig of zo verschillend dat een gemeenschappelijke noemer er niet in kan worden ontdekt. De economie, in het bijzonder de bedrijfseconomie zoals die in Europa wordt gedoceerd, houdt zich vooral bezig met wat wel de structuurtheorie van de organisatie wordt genoemd. ${ }^{4}$ )

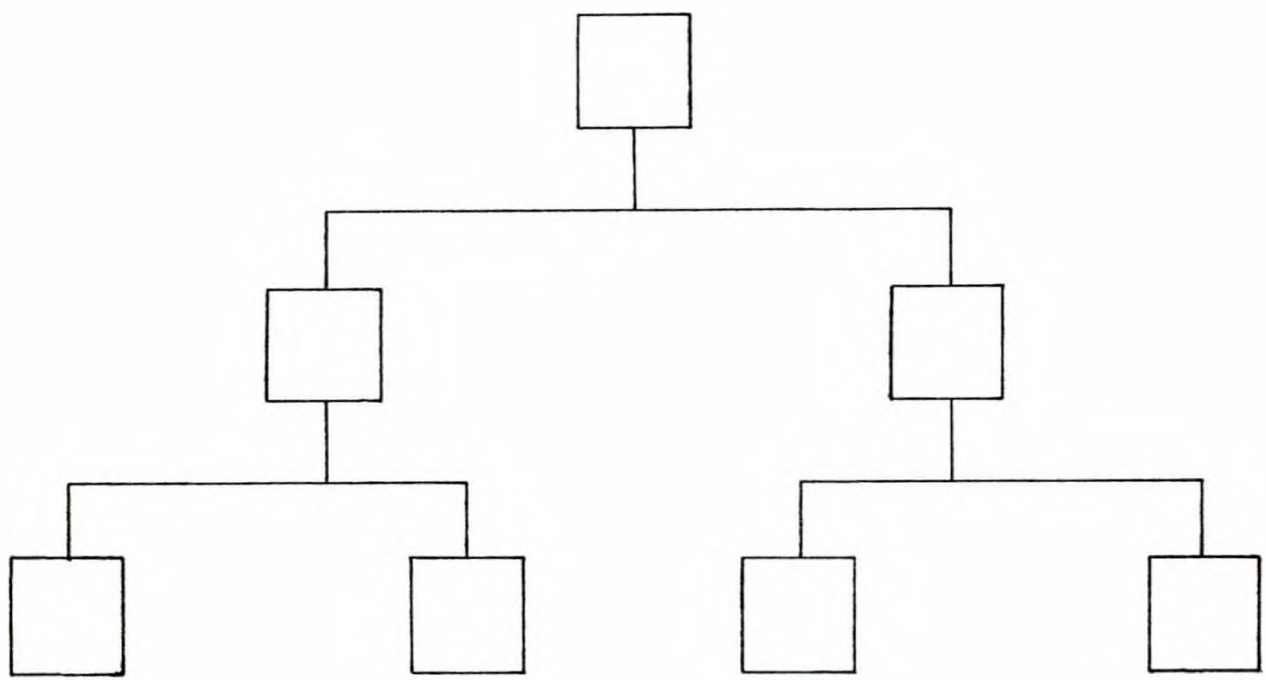

figuur 1

Deze theorie schenkt vooral aandacht aan de opbouw van de formele organisatie, die veelal schematisch wordt weergegeven in de vorm van het organisatieschema (zie figuur 1). ${ }^{5}$ ) Centraal bij de bepaling van de boomstructuur van deze figuur staat het vraagstuk van het omspanningsvermogen. ${ }^{6}$ ) Dit vraagstuk kan economisch worden geïnterpreteerd als een keuzeprobleem. Men kan kiezen uit een verzameling van instrumenten die het omspanningsvermogen vergroten, waardoor het aantal leiders vermindert. Hieruit resulteert een kostendaling, terwijl uit de toepassing van het gekozen instrument een kostenstijging zal voortvloeien. De structuurtheorie gaat veelal uit van enkele impliciete vooronderstellingen. Deze vooronderstellingen zijn:

1 Eén centrale doelstelling, al of niet met randvoorwaarden, waaruit eenduidig doelstellingen voor de lagere niveau's in de organisatiestructuur kunnen worden afgeleid (de zgn. holistische gedragswijze).

3) De grote verscheidenheid in organisatietheorieën brengt met zich mee dat in de hierna te geven tweedeling van deze theorieën een aantal kan worden ondergebracht in beide categorieën. In het kader van dit artikel is het niet mogelijk, overigens ook niet relevant, een verdere onderverdeling in deze theorieën te maken.

4) Zie Marcus Alexis en Charles Z. Wilson: Organizational Decision Making, Englewood Cliffs 1967; Joseph W. McGuire: Theories of Business Bebavior, Englewood Cliffs 1964.

5) In dit artikel wordt op een aantal plaatsen een onderscheid gemaakt tussen formeel en informeel. Formeel is alles wat door de leiding van een organisatie is ontworpen of voorgeschreven en dat ook overeenkomstig deze ontwerpen of voorschriften wordt uitgevoerd. Informeel noemt men de rest. Volledigheidshalve wordt er op gewezen dat informeel niet betekent dat de leiding van de organisatie de daaruit resulterende handelingen of beslissingen niet zou sanctioneren.

$\left.{ }^{6}\right)$ Zie bijv. J. L. Meij: Leerboek der bedrijfseconomie, dl. II, Den Haag 1964. 


\section{Objectief rationeel handelen. ${ }^{\top}$ )}

3 Men gaat ervan uit dat op de lagere niveau's zal worden beslist overeenkomstig de centrale doelstelling.

De structuurtheorie heeft een sterk normatief karakter, d.w.z. men houdt zich vooral bezig met het geven van voorschriften hoe de organisatiestructuur moet worden opgebouwd. De verklarende waarde van deze theorie is beperkt. Het „gedrag" van de organisatie is door de aard van de vooronderstellingen gedetermineerd en volledig voorspelbaar.

Tegen de impliciete vooronderstellingen van de structuurtheorie zijn op grond van de bevindingen in de sociologie en de sociale psychologie bezwaren aan te voeren. Het tegemoet komen aan deze bezwaren bepaalt de vorm en de inhoud van de nieuwe ontwikkelingen op het gebied van de organisatietheorie. Tegen de derde en het tweede deel van de eerste vooronderstellingen richten zich vooral de bezwaren van sociologische zijde. De organisatie wordt gezien als een middel om, vrijwillig of gereglementeerd, te komen tot samenwerking tussen personen of groepen van personen. Deze samenwerking kan niet, in het bijzonder niet in het geval van een samenwerking tussen groepen van personen, met behulp van maatregelen in het financiële vlak eenduidig worden afgestemd op een centrale doelstelling van de organisatie. De relatie is veeleer omgekeerd, de doelstellingen van de organisatie komen tot stand uit het onderhandelingsproces der participanten. $\left.{ }^{8}\right)$ De organisatietheorieën van o.a. Barnard, Likert, Leavitt, Argyris, Merton, Selznick en Simon steunen geheel of gedeeltelijk op deze gedachte.

Het zijn vooral de psychologen, met name die welke zich bezig houden met de psychologie van het denken en daarbij het gedrag (behavior) centraal stellen, die de tweede en het eerste deel van de eerste vooronderstelling hebben aangevochten..$^{9}$ ) Newell, Shaw en Simon hebben daarbij de psychologie van het denken verbonden met het proces van de informatieverwerking. ${ }^{10}$ ) Simon, March en Cyert hebben de uit deze benadering voortvloeiende ideeën uitgewerkt in de vorm van organisatietheorieën. ${ }^{11}$ )

De theorieën van de laatst genoemde auteurs zijn in zoverre volledig dat zowel de bezwaren van sociologische als van psychologische zijde er in zijn verwerkt. De expliciet geformuleerde vooronderstellingen, waarvan zij uitgaan, zijn:

1 Een netwerk van doelstellingen die onderling samenhangen, die niet éénduidig zijn bepaald maar door onderhandelingen tot stand komen.

2 Begrensde (bounded) rationaliteit, de inhoud ervan moet van geval tot geval uit de beslissingsprocedures worden afgeleid.

7) Zie voor een nadere uiteenzetting over het begrip rationeel handelen A. Bosman: „De elektronische rekenmachine: rekenen en redeneren", Bedrijfseconomische Verkenningen, red. J. L. Bouma en H. Willems, Den Haag 1965, en de daar genoemde literatuur.

${ }^{8}$ ) Voor een verdere uiteenzetting zic J. L. Bouma: De toepassing van intern-gedragsmodellen in de bedrijfseconomic, Leiden 1967 en de daargenoemde literatuur.

9) Zie het trefwoord "Thinking and Problem Solving, Psychology of", in de Encyclopaedia Britannica, 1964, deel 22.

10) In Nederland heeft o.a. N. H. Frijda dit gedaan in zijn oratie: Kunnen mensen denken, Amsterdam 1965.

11) James G. March en Herbert A. Simon: Organizations, New York 1961; Richard M. Cyert en James G. March: A Behavioral Theory of the Firm, Englewood Cliffs 1963. Voor cen korte samenvatting over de grondslagen van deze theorie, zie Bosman, t.a.p. Voor een meer gedetailleerde uitwerking, zie J. L. Bouma, t.a.p. en J. L. Bouma: Ondernemingsdoel en winst, Leiden 1966. 
3 De wijze waarop de informatie wordt verkregen en gebruikt, wordt mede in beschouwing betrokken.

De vooronderstellingen één en drie bewerkstelligen dat de daarin vervatte beslissingsprocedures, zeker voor zover het de routinematige beslissingen betreft, van informele aard zijn. In het algemeen zal de vezameling van informele procedures, door de wijze waarop ze tot stand komen, een grote stabiliteit bezitten. De verzameling zal in de korte periode slechts kleine wijzigingen ondergaan.

De drie laatste vooronderstellingen lijken lijnrecht te staan tegenover die waarvan de structuurtheorie uitgaat. Aangezien deze pretendeert een normatief karakter te hebben, rijst de vraag waarop deze pretenties steunen. Immers zouden de hiervoor genoemde bezwaren tegen deze theorie juist zijn, dan zou deze uitgaan van een werkelijkheid die niet bestaat en waarvan derhalve moeilijk voorschriften kunnen worden ontleend. Dat deze tegenstelling in vooronderstellingen niet meer op de voorgrond treedt, is voornamelijk een gevolg van het feit dat de structuurtheorie zich bezig houdt met de formele organisatie. De recente ontwikkelingen van de organisatietheorie daarentegen besteden vooral aandacht aan de informele organisatie en de raakpunten met de formele. Eerst wanneer men tracht beide te integreren worden de gesignaleerde tegenstellingen in de vooronderstellingen reëel. In par. 4 zal hieraan nader aandacht worden besteed.

De rol die de rekenautomaat speelt, bij de ontwikkeling van de nieuwe organisatietheorieën, is die van instrument. Men legt de beslissingsprocedures in de vorm van programma's voor deze automaat vast, om daarna door simulatie het ,gedrag" van de organisatie te onderzoeken. Zo hebben o.a. Cyert en March simulatiemodellen ontwikkeld die, in bepaalde getoetste gevallen, een voor de economie hoge voorspellende waarde blijken te hebben. ${ }^{12}$ ) Door de mogelijkheden die de simulatie biedt, oefent het instrument een grote invloed uit op de vorm en de inhoud van nieuwe theorieën. Alhoewel er geen direct verband bestaat tussen de grondgedachten waarop de nieuwe organisatietheorieën steunen (zie het begin van deze paragraaf) en de ontwikkeling van het instrument, kan niet worden ontkend dat de problematiek van de automatisering en de mogelijkheden van de rekenautomaat juist het realiteitsgehalte en de mogelijkheid van toepassing van de nieuwe theorieën hebben aangetoond. De rekenautomaat is bij de simulatie een onmisbaar hulpmiddel.

\section{De huidige toepassingen van de rekenautomaat}

Naast de zojuist genoemde toepassing van de rekenautomaat op het terrein van de verklarende wetenschap, kunnen drie toepassingsgebieden worden onderscheiden die in de praktijk als veel belangrijker worden ervaren. Deze gebieden zijn:

1 Dat van de informatieverwerking, voornamelijk het werkterrein van de administratieve automatisering.

2 Dat van de beslissingsvoorbereiding, voornamelijk het werkterrein van het operationeel onderzoek.

3 Dat, wat men het verrichten van rekenwerk zou kunnen noemen.

12) Het ligt voor de hand hieruit te concluderen dat de verklarende waarde van deze theorie groter is dan die van de structuurtheorie. Deze conclusie mag echter niet zonder meer worden getrokken. Zie voor een verklaring hiervoor en een aantal andere problemen rond de simulatie, A. Bosman: „Simulatie”, Maandblad voor Accountancy en Bedrïfshuishoudkunde, jrg. 42 (1968), nr. 5 . 
Dit laatste toepassingsgebied wordt hier verder buiten beschouwing gelaten. De eerste twee toepassingen worden op dit moment, gezien vanuit de gezichtshoek der organisatietheorie, veelal beheerst door de structuurtheorie. Het gevolg daarvan is de ontwikkeling van zgn. optimale systemen. ${ }^{13}$ ) Systemen die enerzijds door de toepassing van operationele onderzoektechnieken optimale oplossingen moeten garanderen en die anderzijds, uitgaande van de structuurtheorie, zijn gebouwd op geautomatiseerde optimale administratieve organisatiestructuren. Om dit te bereiken maakt men in beide gevallen gebruik van programma's van algoritmische aard. ${ }^{13}$ )

De ontwikkeling van de eerste generatie toepassingen wordt bepaald door dit streven naar een optimum in beide genoemde toepassingsgebieden. Helaas ontwikkelen deze beide zich vrijwel onafhankelijk van elkaar. Dit heeft voor de informatieverwerking met behulp van de rekenautomaat bepaalde gevolgen. De informatie die door de administratieve programma's wordt verwerkt, onderscheidt zich in de inhoud van de uitvoer niet van die, welke uit een met de hand gevoerde administratie resulteren. De informatie die men voor vrijwel alle operationele onderzoektechnieken nodig heeft, kan slechts bij hoge uitzondering direct aan het bestaande administratieve apparaat worden ontleend. ${ }^{14}$ ) Dit heeft weer tot gevolg dat aan de technische outillage van de rekenautomaat door beide toepassingsgebieden andere eisen worden gesteld.

1 In de administratieve automatisering kan men veelal volstaan met een relatief kleine rekenautomaat, die de mogelijkheid moet bieden sequentieel een groot extern geheugen te raadplegen. Dit laatste kan dan dikwijls een magneetbandgeheugen zijn.

2 Voor de toepassing van de bekendste technieken uit het operationeel onderzoek is meestal een relatief grote rekenautomaat met een extern geheugen, dat niet direct toegankelijk behoeft te zijn, noodzakelijk.

Zelfs de combinatie van beide schept nog niet de voorwaarden om grote systemen, met de mogelijkheid van on-line verbindingen en uniform toegankelijke externe geheugens, te installeren.

Deze tegenstelling tussen wat technisch mogelijk is en het gebruik dat er van wordt gemaakt, is een onderwerp waarover de laatste tijd veel wordt gediscussieerd. ${ }^{15}$ ) De discussie samenvattend, kan men stellen dat de belangrijkste oorzaak hiervoor moet worden gezocht in het feit dat men niet in staat is een inhoud te geven aan het begrip totale systeem. Hèt kenmerk van een dergelijk systeem is dat de gegevens, waarover men in een organisatie moet kunnen beschikken, slechts op één plaats worden vastgelegd. Dat betekent dat alle communicatiepatronen in

13) Voor een uiteenzetting over het begrip systeem zie A. Bosman: „Systemen”, Maandblad voor Accountancy en Bedrijfshuishoudkunde, jrg. 42 (1968), nr. 4.

14) Administratie wordt hier ruim gedefinieerd. Er wordt onder verstaan het geheel van aktiviteiten noodzakelijk voor het ontwerpen en het opzetten van gegevensbestanden en het muteren van bestaande bestanden. De gegevens kunnen zowel van technische, commerciële als financiële aard zijn. In het midden wordt gelaten welke bestanden een administratic moet bevatten of hoe de mutaties moeten worden verwerkt. Daarover kan, zonder het doel waarvoor de gegevens moeten worden gebruikt mede in de beschouwing te betrekken, geen uitspraak worden gedaan.

15) Zie S. H. Waringa: "Naklanken van een negende", Maandblad voor Accountancy en Bedrijfshuishoudkunde, jrg. 42 (1968) nr. 3; commentaar op de discussie over dit onderwerp in Informatie geven: A. B. Frielink: „Naar aanleiding van organisatie, interne controle en informatietechniek” en S. H. Waringa: „Een lichte deining”, Informatie, jrg. 9 (1967), nr. 718. 
de organisatie moeten worden omschreven en dat de inhoud ervan moet worden bepaald. Dit is alleen mogelijk indien men aan de belangrijkste reden voor de informatie-uitwisseling, het nemen van beslissingen, een inhoud kan geven. In een nieuwe theorie van de organisatie hoort het nemen van beslissingen en de daarvoor noodzakelijke informatieverwerking dan ook centraal te staan.

\section{Organisatie en automatisering}

Beslissen omvat twee fasen:

a bepalen of er een beslissing moet worden genomen;

$b$ het doen van een keuze uit een verzameling alternatieven.

Het onderscheid in deze twee fasen valt gedeeltelijk samen met een tweetal andere nl., enerzijds met dat tussen pragmatische en semantische informatie en anderzijds met dat tussen planning en besturing.

Het begrip informatie is verbonden met de begrippen teken en signaal. De laatste is de informatiedrager waarmee de tekens worden overgebracht van een zender naar een ontvanger - het proces van communiceren. De betekenis van de tekens - de informatie - kan op verschillende manieren worden gemeten. Bij de syntactische informatie gaat het om de bepaling van de zgn. objectieve informatie. Deze wordt gevonden door het bestuderen van de relatieve frequenties der tekens en de relatie daartussen. Bij de semantische informatie gaat het om de relatie tussen de tekens en de alternatieven, terwijl de pragmatische informatie de betekenis van een alternatief voor de ontvanger weergeeft. Deze drie begrippen informatie kunnen niet onafhankelijk van elkaar worden behandeld. Zo zal men voor de bepaling van de semantische informatie mocten kunnen beschikken over een code (syntaxis) om de tekens te kunnen vertalen, terwijl men voor de bepaling van de pragmatische informatie een verband moet kunnen leggen tussen alternatief en ontvanger. ${ }^{16}$ )

Onder planning wordt hier verstaan het bepalen van de waarden der endogene variabelen in een model, gegeven de schatting van de waarden der exogene variabelen. De oplossing van het model geeft in de vorm van de waarden der endogene variabelen het alternatief weer dat werd gekozen. Besturing is ruimer. Door middel van terugkoppeling, vergelijking van de norm met de realiteit, wordt eerst beslist of er bepaalde maatregelen moeten worden genomen. In het geval dit zo zou zijn, wordt op grond van de grootte van de afwijking tussen norm en realiteit een bepaalde maatregel gekozen. ${ }^{17}$ )

Er kan een verband worden gelegd tussen enerzijds de pogingen om de rekenautomaat in te schakelen in het besturen van de bedrijfshuishouding en anderzijds de zojuist besproken drie onderscheidingen. Dit verband is als volgt. De tweede fase van het beslissingsproces bestaat uit het toekennen van semantische informatie aan de elementen uit de verzameling alternatieven. Daarvoor is vereist:

a Dat de code van de tekens, die de informatie bevatten, aan de ontvanger bekend is.

$b$ Dat de verzameling alternatieven waaruit moet worden gekozen eindig is, terwijl het aantal elementen van de verzameling bekend moet zijn.

16) Voor een verdere uiteenzetting wordt men verwezen naar C. A. van Peursen, C. P. Bertels en D. Nauta: Informatie, Aula-boek nr. 356, Utrecht 1968 en Colin Cherry: On Human Communication, New York 1961.

17) Voor het onderscheid tussen planning en besturing zie, A. Bosman en H. G. Werkema: "Produkticplannıng en produktiebesturing", Maandblad voor Bedrijfsadministratie en -organisatie, jrg. 69 (1965), nr. 814. 
c Dat er een criterium is waarmee de alternatieven kunnen worden geordend. Dit criterium bevat dan de zgn. selectieve informatie, vereist voor het toekennen van semantische informatie. In het algemeen voldoen de planningtechnieken, met name die uit het operationele onderzoek, aan de gestelde voorwaarden. Wordt daaraan voldaan, dan is het mogelijk de rekenautomaat in te schakelen bij het toekennen van semantische informatie. ${ }^{18}$ )

Problemen bij de informatieverwerking, overigens niet alleen bij toepassing van de rekenautomaat zij het dat ze zich dan meestal duidelijker manifesteren, ontstaan vooral door drie oorzaken.

1 De verzameling alternatieven is niet eindig, of het aantal elementen in de verzameling verandert voortdurend.

2 Het verband dat moet worden gelegd tussen de situatie waarin de ontvanger zich bevindt, men zou ook kunnen zeggen de toestand van de ontvanger, en de alternatieven waarop de semantische informatie betrekking heeft. ${ }^{19}$ )

3 De code van de tekens is de ontvanger niet bekend. Dit betekent dat deze verkeerd of in het geheel niet worden vertaald.

De drie oorzaken treden dikwijls simultaan op. Met de technieken die ons ter beschiklking staan, kunnen we geheel of gedeeltelijk elk der oorzaken, indien zij tenminste afzonderlijk optreden, onderkennen en opvangen. De eerste oorzaak kunnen we gedeeltelijk opvangen met behulp van een besturingsmodel, in de betekenis die de cybernetica daaraan toekent. Slechts gedeeltelijk, omdat dit alleen slaagt indien de norm de selectieve informatie bevat en deze niet zelf een variabele wordt onder invloed van veranderingen in de verzameling alternatieven. De tweede oorzaak kan tegemoet worden getreden door een verder gaande specificatie van beide typen toestanden, nl. die van de ontvanger en die, welke wordt gerepresenteerd door de alternatieven. Het zijn met name de onderzoekingen in de nieuwe organisatietheorieën die een deel van deze specificatie kunnen leveren. Voor het analyseren van de derde oorzaak kunnen bepaalde technieken, zoals die van de filters, worden gebruikt. Toepassing hiervan op niet technische problemen zijn schaars. Voor de combinatie van de drie oorzaken bestaan nog geen adequate theorieën en technieken. Het moet sterk worden betwijfeld of die op korte termijn zullen worden gevonden. Dit betekent dat bij het zoeken van toepassingen van de rekenautomaat op het gebied van de besturing van de bedrijfshuishouding vooral de aandacht zal moeten worden gericht op de automatisering van problemen, die met behulp van planningmethoden kunnen worden opgelost.

Het automatiseren van de beslissingen in de bedrijfshuishouding moet daarom niet beginnen bij die, welke in de top van de organisatiestructuur worden genomen. De massa der beslissingen wordt gevormd door die met een routinekarakter, men denke in dit verband aan de budgettering en de werkvoorbereiding. Aangezien deze beslissingen veelal niet of nauwelijk worden beïnvloed door externe verstoringen, lenen zij zich uitstekend voor een benadering met behulp van planningmethoden. In bepaalde gevallen kunnen, juist door het ontbreken van externe ver-

18) Het valt in dit verband te betreuren dat de term computer in het nederlands vaak wordt vertaald met informatieverwerkende apparatuur. Een groot deel van de nu gebruikte programma's verwerken slechts data en kennen daaraan geen informatieve waarde toe.

19) Toestand en alternatief komen, voor zover het een toekomstige situatie betreft, overeen. Een toestand $\mathrm{kan}$ in het algemeen worden omschreven als een specificatie van het geheel van zakelijke omstandigheden. Het heeft, zoals hier gedefiniecrd, dezelfde betekenis als het begrip toestand in een systcem, zie A. Bosman: „Systemen”, t.a.p. 
storingen of door de mogelijkheid die men in het algemeen dan heeft om deze verstoring te classificeren, ook besturingsmodellen worden gebruikt. De mogelijkheid tot het realiseren van besparingen bij toepassing van de automatisering moet dan ook worden gezocht in het automatiseren van deze routinebeslissingen.

Indien men de beslissingsprocedures beschouwt die nu in een bedrijfshuishouding bestaan voor het nemen van routinebeslissingen, blijkt duidelijk welke grote discrepantie er bestaat tussen de eerste en derde vooronderstelling van de structuurtheorie en de werkelijkheid. De informele procedures, die rond deze beslissingen zijn gevormd, zijn te beschrijven, en daarmee programmeerbaar, met behulp van de hypothesen van de moderne organisatietheorieën. Ze zijn slechts bij uitzondering te herleiden uit de zgn. centrale doelstelling van de bedrijfshuishouding, zo deze al zou bestaan. Dat het holistische ondernemingsgedrag en het objectief rationeel handelen uiteindelijk noodzakelijk zijn om tot een normatieve bedrijfseconomie te komen, zoals Goldschmidt stelt, is onjuist. ${ }^{20}$ ) Op een praktisch hanteerbare wijze kunnen aan de moderne organisatietheorie normatieve uitspraken worden ontleend. Daarvoor kan men de bestaande beslissingsprocedures met behulp van simulatie vergelijken met andere, die, naar de mening van deskundigen om welke redenen dan ook, betere resultaten zouden geven. In deze redenen liggen de verschillen tussen de aanhangers van de structuurtheorie en die van de moderne organisatietheorieën.

Het toepassen van de optimalisatiegedachte bij het ontwerpen van normen zal er toe leiden dat men:

a slechts oplossingen kan geven voor deelproblemen. De verzameling van partiële optima is zelf veelal geen optimum, terwijl het verband met de problemen waarvoor geen optimum kan worden gevonden, verloren gaat. ${ }^{21}$ ) Bovendien geven deze partiële optima geen oplossing voor de problemen van de laagste leidinggevende niveau's. Daar gaat het immers vooral om de toewijzing van de activiteiten, in de zin van onderdelen en orders, aan produktiefaktoren (job-shop scheduling);

$b$ de gegevens voor het oplossen van deze problemen worden niet aan de administratie ontleend, zodat deze laatste los blijft staan van de beslissingssfeer.

Uitgaande van de moderne organisatietheorie kunnen de beslissingsprocedures en de daarvoor vereiste invoer aan gegevens worden omschreven. Op deze wijze ontstaat een netwerk, zie figuur 2, waarin de pijlen stromen gegevens en de knooppunten beslissingscentra weergeven, terwijl de vierkanten bestanden voorstellen.

${ }^{20}$ H. O. Goldschmidt: De doeleinden van de onderneming, Leiden 1966.

21) Toepassing van bijv. de formule voor de bepaling van de optimale bestelhoeveelheid bij in serie geschakelde bestelpunten zal bij een verstoring van de vraag d.m.v. het zgn. Forrester effect veelal tot een grotere instabiliteit leiden dan bij het gebruik van een bestelhoeveelheid, die mede wordt bepaald door de overweging vraagverstoringen „tijdig" door te geven. 


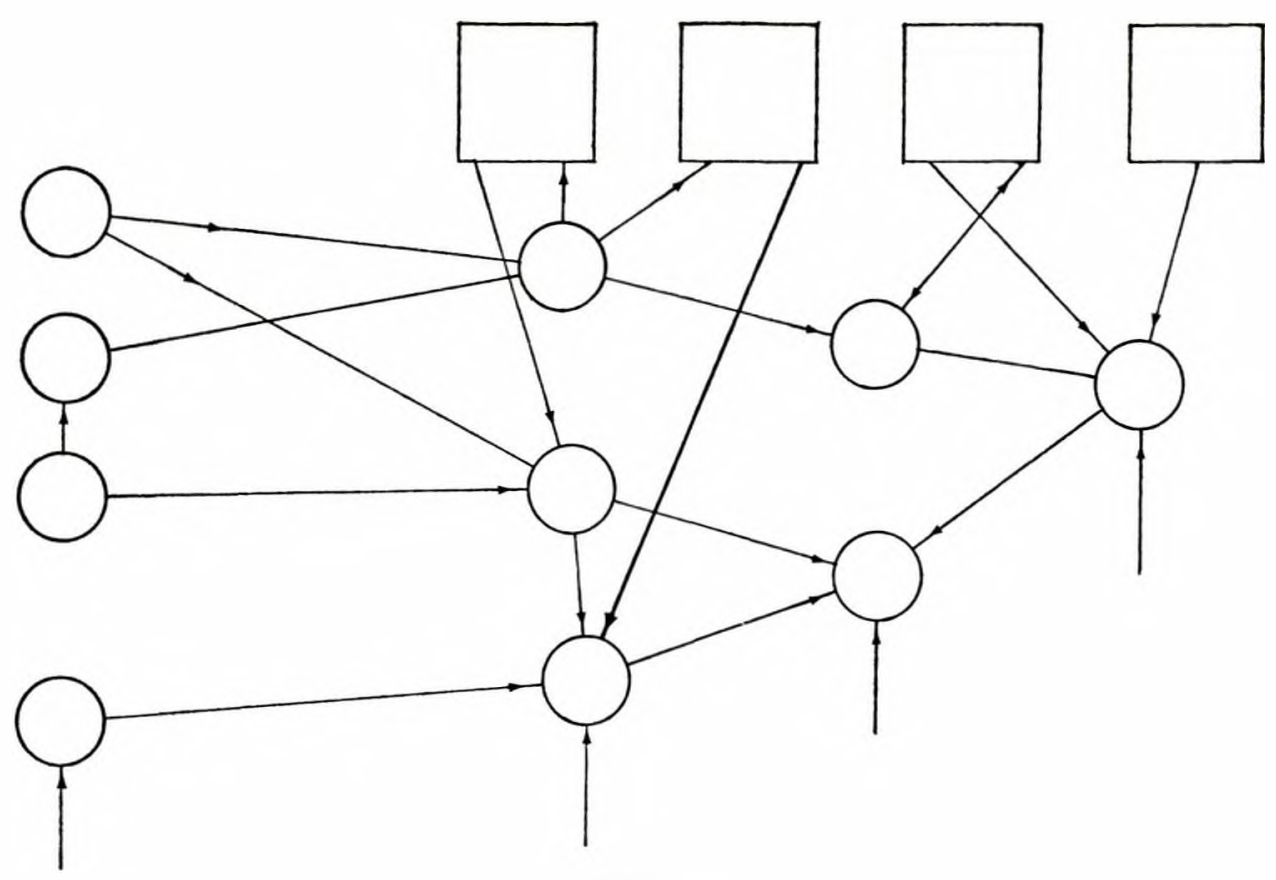

figuur 2

De pijlen zijn gericht en kunnen in beide richtingen wijzen. Elk beslissingscentrum kan door de zgn. zwarte doos (black box) worden getypeerd, (zie figuur 3).

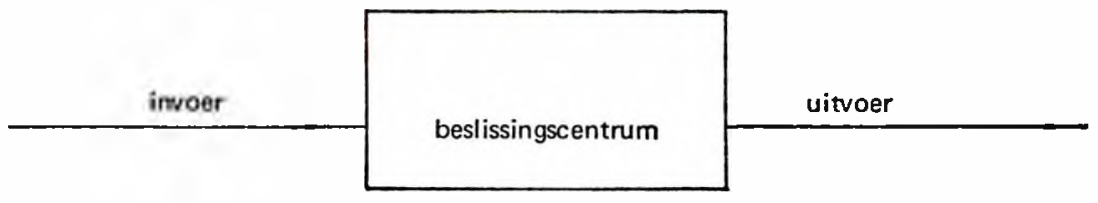

figuur 3

De invoer moet in dit geval worden onderscheiden in twee delen. Het eerste deel wordt bepaald door de invoer afkomstig uit andere beslissingscentra, het tweede door de invoer afkomstig van buiten het systeem en uit de bestanden. De beide laatste typeren de toestand waarin het betrokken beslissingscentrum verkeert. ${ }^{22}$ )

De relaties tussen alle beslissingscentra en de toestanden waarin deze kunnen verkeren, bepalen de wijze waarop het systeem, in casu de organisatie, zich ,gedraagt". De werking van het systeem is nu niet alleen afhankelijk van de relaties tussen de beslissingscentra, maar tevens van externe omstandigheden. Door het begrip toestand expliciet in de beschouwing te betrekken wordt hier rekening mee gehouden. Dit laatste is van essentieel belang, omdat vele beslissingsregels het in bepaalde toestanden wel goed blijken te doen, maar in andere soms tot niet gewenste resultaten leiden. Bij de opbouw van het systeem is het noodzakelijk dat alle beslissingscentra worden opgenomen. De zwarte dozen kunnen worden gevuld

22) Hierbij moet worden opgemerkt dat voor vele beslissingscentra de invoer van buiren het systeem zich vooral laat gelden via mutaties in de bestanden. 
aan de hand van de richtlijnen die de moderne organisatietheorie daai voor geeft. In het normatieve vlak kunnen de in de beslissingscentra toegepaste beslissingsregels worden veranderd en of, in het geval van de beslissingen die op de lagere niveau's van de leidinggevende structuur worden genomen, voor de rekenautomaat worden geprogrammeerd.

\section{Tweede generatie toepassingen en het verband met de structuurtheorie}

Indien men programma's kan ontwikkelen die een oplossing geven van het probleem van de job-shop scheduling kan een groot deel van de lagere niveau's van de leiding worden geautomatiseerd. ${ }^{23}$ ) In dat geval is het mogelijk de geautomatiseerde administratie op een logische wijze in het geautomatiseerde beslissingssysteem te passen en de resultaten van de beslissingen direct of via mutaties in de bestanden door te geven. Juist de oplossing van het probleem van de job-shop scheduling maakt deze integratie met de administratie, uit bestuurlijk oogpunt gezien, zinvol, omdat deze beslissingen de offers binnen de onderneming voor een belangrijk deel bepalen. Het behoeft geen betoog dat lang niet alle beslissingen binnen een onderneming kunnen worden geautomatiseerd. Een belangrijk deel van de beslissingen, met name die op de hogere niveau's in de organisatie, zullen door mensen moeten worden genomen, zij het dat de technieken van de beslissingsvoorbereiding hierbij steun kunnen verlenen. Wel van belang is echter dat de beide beslissingen elkaar wederzijds beïnvloeden. Deze beïnvloeding, hiervoor vertolkt in de voorwaarde dat in het systeem beslissingscentra moeten zijn opgenomen, maakt het mogelijk aan de slogan „mens - machine dialoog” een operationele inhoud te geven. Ervan uitgaande dat voor het automatiseren van de routinebeslissingen, de daarbij behorende informatieverwerking en de daarop aangesloten administratie een uniform toegankelijk massageheugen noodzakelijk is, kunnen in dit geheugen ook bestanden worden gevormd die noodzakelijk zijn voor het beantwoorden van vragen in de sfeer van de beslissingen op de hogere leidinggevende niveau's.

De mogelijkheid beslissingen op de laagste leidinggevende niveau's te automatiseren, heeft ondermeer tot gevolg dat het grote verschil tussen de structuurtheorie der organisatie en de moderne versies der organisatietheorieën gedeeltelijk zal verdwijnen. Immers door het programmeren van deze beslissingen krijgen deze een formeel en eenduidig bepaald karakter. Hiermee wordt dan voor de lagere niveau's van de leidinggevende arbeid voldaan aan enkele van de impliciete vooronderstellingen waarvan de structuurtheorie uitgaat. Een ander verband tussen beide hier genoemde stromingen in de organisatietheorie is de relatie die er bestaat tussen de systemen geschetst in figuur 1 en 2 . Figuur 1 is een boomstructuur waarvan de belangrijkheid en het functioneren der daarin voorkomende takken moet worden bepaald. Voor een belangrijk deel is het antwoord op deze vraag afhankelijk van de beslissingscentra en de daartussen bestaande relaties die in elk van deze takken voorkomen. Ervan uitgaande dat een hiërarchische opbouw van de organisatiestructuur noodzakelijk is op grond van gezagsverhoudingen, kan deze structuur vaak beter aan de informele worden aangepast door rekening te houden met de in de organisatie voorkomende communicatiepatronen.

${ }^{23}$ ) Een beschrijving van twee systemen die op dit gebied in de V.S. werken geeft Elwood S. Buffa: Production-Inventory Systems: Planning and Control, Homewood, 1968. Voor een beschrijving van één van de twee, zie ook Stanley Reiter: „A System for Managing Job-Shop Production", The Journal of Business, S. Vol. 34 (1966), nr. 3. 